\title{
State formation on China's southern frontier: Vietnam as a shadow empire and hegemon
}

\author{
Tuong $\mathrm{Vu}^{1}$
}

\section{Introduction}

State formation in the territory called "Vietnam" today followed an imperial pattern, namely a process of conquests and annexations typical of an empire. Emerging out of "Chinese" rule in the tenth century, the "Vietnamese" expanded their territory hundreds of miles north and west and a thousand miles south to annex areas populated by Nùng, Thái, Mường, Chàm, Khmer, and others. ${ }^{2}$ At its peak in the early nineteenth century, the frontier of the Nguyễn empire encompassed much of today's Cambodia and Laos. This imperial pattern was the basis on which the French built their Indochinese colony and the Vietnamese communist state built its modern hegemony.

An account of Vietnam as an empire and hegemon challenges the nationalist historiography which emerged in colonized Vietnam a century ago and which remains influential today. ${ }^{3}$ In this historiography, Vietnam is essentialized as home to an ancient and unified nation with an indomitable spirit, while China is imagined as a big bully bent on but never successful in subjugating that spirit. Not too long ago, many prominent scholars were still preoccupied with the question of how the Vietnamese were able to maintain their identity and independence throughout their 2000-year recorded history in the shadow of its giant northern neighbor. ${ }^{4}$ The threat of assimilation and annexation by "China" is often portrayed as the paramount existential problem confronting all "Vietnamese" throughout their history who have yearned to preserve their independence even while adapting to "Chinese" culture and worldview.

Nationalist historiography ignores the inconvenient fact that for much of "Chinese" and "Vietnamese" history, there have been centuries-long periods when more than one "China"

1 Acknowledgments: This paper benefited from many helpful comments and suggestions of James Anderson, Hans Hägerdal, Liam Kelley, Ben Kerkvliet, Claire Sutherland, and two anonymous reviewers.

2 For the most parts I try to avoid the modern terms "China," "Chinese," "Vietnam," and "Vietnamese" when referring to premodern polities and peoples. If unavoidable, efforts are made to convey their modern origins. For premodern China, "the Middle Kingdom" [Zhongguo] or "the northern empire" (north viewed from the Red River Delta) are used. For premodern Vietnam, An Nam and Đại Việt are used interchangeably. The former term ("peaceful South") was given to Jiaozhou (the northern and north-central part of today's Vietnam) in 679 while it was under Tang rule. The name Đại Việt was first used by a Lý monarch in mideleventh century (Taylor 2013: 38-9, 72). An Nam has tended to be avoided in the nationalist historiography for its association with Chinese domination despite the fact that it was widely used in premodern Vietnam, and (as referring to central Vietnam) during the French colonial period. In fact, "An Nam" was used more commonly than Đại Việt in premodern Vietnam, and used not only in official communication between Vietnam and China but also in personal communication between Vietnamese envoys and those from other kingdoms when they met in the Chinese capital (Kelley 2005: 25).

3 For a critique of nationalist historiography, see Tran and Reid 2005.

4 Notable examples are Marr 1971 and Taylor 1983. 
and one "Vietnam" existed. Even if limited to those times when a single "Vietnam" confronted a single "China," the nationalist narrative is seriously misleading. While some ambitious rulers from the north have sought to dominate the people of historical Vietnam, the Chinese empire did not endanger the survival of their country as much as other groups on China's southern frontier. Tang rulers gave the frontier Jiao province (today's northern and north-central Vietnam) the name "An Nam," meaning the "Peaceful South," yet the name perhaps reflected their wish rather than the reality (Woodside 2007: 16). The "Violent South" would have more accurately captured the reality of China's southern frontier. As I argue, the Middle Kingdom directly or indirectly aided Annamese in their quest to expand power along that frontier.

This positive synergy is often neglected in studies that focus exclusively on SinoVietnamese dyadic interactions. ${ }^{5}$ While insightful, works along this line have tended to posit the two as opposites, whether their relationship was placed on an asymmetric or more equal basis. ${ }^{6}$ By situating Vietnamese state formation in the context of China's southern frontier, ${ }^{7} \mathrm{I}$ hope to present the Sino-Vietnamese relationship in a different light, one that has more often contained a positive rather than negative synergy. Treating Vietnam as an empire or hegemon on a large area of mainland Southeast Asia is also essential to understand why the Vietnamese sometimes did not automatically accept Chinese superiority despite the obvious "asymmetry" between them. In fact, we will see that ambitious Vietnamese leaders have at times imagined or claimed superiority over their northern neighbor, for better or worse.

This essay includes four sections. First, I will briefly discuss the four concepts of periphery, frontier, empire, and hegemon. These are well-known concepts in history and the social sciences, and my goal is not to tackle the complex debates about them, but rather to offer some definitions and note how they may contribute to our understanding of Vietnam as a shadow empire and hegemon. The term "shadow empire" used here is borrowed from scholars studying state formation on the steppe along the northern border of the Chinese empire. That term applies only in the premodern period, and I have coined the term "shadow hegemon" for the modern period. "Shadow" here means not only that small-sized Vietnam was overshadowed by giant China, but also that at least a certain positive synergy existed between them in both premodern and modern time.

The second part of the essay contrasts the northern and southern frontiers of the Chinese empire to tease out distinctive economic, political, and historical conditions of the southern frontier that have shaped its relationship with China. This comparison of the two frontiers suggests that for much of premodern history northern rulers had no compelling rationale to seek direct control over their "Peaceful South." Imperial rulers were certainly concerned

5 For example, see Womack 2006. A recent exception is Anderson and Whitmore 2015: 1-58.

6 While Brantly Womack emphasizes asymmetry, James Anderson divides the history of Sino-Vietnamese tributary relations into three basic situations characterized by the relative domestic strength of each country's rulers (strong China/weak Vietnam; strong China/strong Vietnam; weak China/strong Vietnam) (Womack 2006; Anderson 2013: 259-280).

7 For a recent study that treats the residents of the Red River Delta as sharing the Yue/Việt identity of people who lived in the entire Hua-xia region, which was early China's southern frontier, see Brindley 2015. 
about all the borderlands that encircled the empire,${ }^{8}$ but the nature of the threat posed to their security by the northern and southern frontiers was totally different. The third part will attempt to explain how premodern Đại Việt [Great Việt] emerged and became a shadow empire, and the fourth section examines modern (communist) Vietnam as a shadow hegemon. In the conclusion, I will briefly speculate on the implications for the current tensions between China and Vietnam in the South China Sea.

A final note should be included about methodology and sources. This essay employs the comparative historical method more commonly used in sociology and political science than in history. This method involves tracing and comparing major political and social developments of human communities over long periods. ${ }^{9}$ The longue durée helps identify major patterns of change and continuity, while (implicit or explicit) comparisons relativize the particular experiences of every community. In terms of sources, this essay draws from various secondary sources that are insightful but have not been brought to bear on the imperial character of Vietnamese state formation in the premodern period. The goal is not to present new findings but rather to build a historiographical case against the erroneous but popular nationalist narrative. In contrast, the arguments for the modern period are drawn from a book in press that relies on primary Vietnamese materials and archival research ( Vu 2017). From the available evidence an interesting parallel between the premodern and modern pattern can be observed.

\section{Periphery, Frontier, Empire, and Hegemon}

In its most basic meaning, periphery is simply "a line that forms the boundary of an area" or "an outermost part or region within a precise boundary." (The American heritage 1993). Similarly, frontier's essential meaning is "an international border" or the area along that border (the American heritage 1993: 547). Periphery is similar to frontier if seen from the perspective of the state. Both denote zones where state power is perhaps weakest (The American Heritage 1993: 547). Beyond their literal meanings, periphery and frontier carry connotations that make them contentious in many scholarly debates.

Periphery suggests a marginal and dependent status when it is paired with "core" or "center." To be on the periphery or to be peripheral means to have less importance or significance. Immanuel Wallerstein's world-system theory, for example, divides the world into three zones: the core, the periphery, and the semi-periphery (Wallerstein 1974). In this framework, the periphery is more dependent on the core than vice versa, and is subject to exploitation and oppression by the core.

While periphery conveys a negative connotation, frontier has a positive meaning. Drawn from its original meaning, frontier refers to an outermost region where people of a country have recently settled, as in the Western United States in the nineteenth century (Kellerman 2007: 230-4). The implication is that a wild, unknown, and uncivilized world exists beyond the frontier. In a related sense, frontier also means the boundary of knowledge in a field of

\footnotetext{
8 For center-frontier relations in China, see Lary (2007); for post-Qing period, see Cochran and Pickowicz (2010); for China's relations with nomadic states and peoples on the northern frontier, see Di Cosmo 2002 and Barfield 1992); for frontier conquests and colonization under the Han Dynasty, see Chang (2007). 9 For a bold statement about this method from a prominent sociologist, see Tilly 1989.
} 
study. To be on the frontier does not mean to be marginal or insignificant as to be on the periphery does. Rather, it suggests a vanguard status and a sense of excitement for being on the "cutting edge" of knowledge or for being the agents of civilization, however understood (Kleinfeld 2012: ix). It is this sense of frontier that explains why many premodern Vietnamese elites felt proud of being part of the Sinicized world and sought to impose Sinic institutions and cultures on neighboring Cambodia when they had the opportunity in the nineteenth century. ${ }^{10}$

Both frontier and periphery imply distance from the core/center, but frontier is implicitly "closer" to the center than periphery. Frontier represents the farthest reach of the center's cultural, economic, and political influence, whereas periphery merely indicates a hierarchical relationship with the center. A strong and expanding frontier is indicative of a powerful center, whereas a strong and expanding periphery may imply a threat to the center's domination.

The contradicting connotations of periphery and frontier suggest that one should be careful in assessing their perspective toward the center. Even though a frontier community is literally one on the periphery of a country, members of the community do not necessarily feel dependent on and marginalized by the center, but may proudly imagine themselves being the vanguards. We will see below how Vietnamese Communist leaders imagined themselves being the vanguards of world revolution even though they were in every other sense peripheral to the communist bloc.

Empire is the most controversial concept among our four concepts. In the standard definition, "empire" is a form of political organization created by military conquests which often encompasses a broad territory inhabited by people of different cultures. Empires are typically characterized by authoritarian rule with the center enjoying political domination throughout the realm. Hierarchy and diversity are thus the hallmarks of empire, as egalitarianism and unity are for the nation. ${ }^{11}$ Unlike in the past when it generated awe and respect, the word "empire" today carries a negative connotation. Yet traditional empires were extremely complex organizations, given their vast territories and great diversity. Although empires were built by conquests and annexations, stable and successful imperial rule involved much more than the use of coercion. Ruling elites of an empire often granted substantial autonomy to local elites in the periphery in return for their support. Imperial rule often relied as much on ideological persuasion as on coercion.

A major debate on empires involves the question whether they still exist today. Many historians of the Cold War consider the Soviet-led and American-led camps as "informal empires" even though the two superpowers did not dominate their client states to the same degree found in traditional empires (Lundestad 2012; Westad 2005). Other scholars distinguish between empire and dependence, arguing that formal or informal empires necessarily involve effective imperial control of sovereignty, whereas dependence means simply unequal influence (Doyle 1986: 40-3). In this view, the American and Soviet 
"empires" represented merely dependent but not imperial relationships. They should be called "hegemons," not "empires."12

In the literature of international relations, hegemons are defined as states that predominate over others, through either mere material dominance or in combination with legitimacy. ${ }^{13}$ Neo-Gramscian authors stress the importance of cultural and ideological hegemony rather than mere military and economic hegemony. Although a case can be made that Vietnamese communists earned some legitimacy from many of their Laotian and Cambodian comrades for providing effective leadership of the movement over the entire Indochina, it should not be controversial, as I do in this essay, to view modern Vietnamese hegemony over Indochina in the material sense.

The four concepts of periphery, frontier, empire, and hegemon are useful as theoretical tools to guide our thinking of Vietnam. The existence of premodern Vietnam in the shadow of the Chinese civilization, or the dependency of modern communist Vietnam on the Soviet Union and China did not automatically mean Vietnam itself could not be an empire or hegemon. As an empire, Vietnam was certainly not in the same league with the giant Chinese or Ottoman empires. Yet Vietnam can be called a "shadow empire," a term coined by Thomas Barfield who uses it to refer to the nomad states on the steppe along the northern border of the Chinese Empire (Barfield 2001: 10-41). These shadow empires of nomad tribes such as the Xiongnu and the Mongols conquered vast territories and created stable rule over them, even though they were much less centralized and sophisticated than "primary empires" such as the Chinese or Ottoman empires. Like those tribes on the steppe, Vietnam has existed in the shadow of China since its birth in the Red River Delta. Nevertheless, its people managed to conquer large territories from other groups on the frontier and have dominated the Indochinese peninsular for several centuries.

\section{The southern versus northern frontier of China}

Scholars of premodern Vietnam have tended to limit the scope of their inquiry to SinoVietnamese relations, but a comparison between China's southern and northern frontiers can illuminate neglected but fundamental aspects of Sino-Vietnamese interaction. A key difference between the two frontiers was the much greater distance from the southern frontier to the "Central Plain" [zhongyuan], where the center of Chinese civilization and political power was located. Three thousand years ago, that center emerged in the middle-lower basin of the Yellow River in northern China. It later expanded to the middle basin of the Yangzi River during the Qin and Han dynasties about two thousand years ago to form the core of Han Chinese civilization (Hsu 2012: 73-7). All urban centers and capital cities of various "Chinese" polities at the time were located within this area. The trip from the Red River Delta to Loyang, the Western Han capital, covered approximately 1,800 miles and took about six months at the time (Taylor 1983: 57). In contrast, the Central Plain was located right next to the steppe where nomadic tribes roamed. The proximity of the steppe to the heart of the Central Plain meant that the nomads could pose direct security threats to its rulers. From so

12 For a perceptive distinction between "empire" and "hegemony," see Schroeder 2009: 61-88.

13 For an extensive discussion of the concept of "hegemony" in international relations, see Clark 2011, esp. 1823. For Gramscian applications in international relations, see Gill 1993. 
far away, Southeast Asians could at best create disturbances along the frontier but were never able to threaten the survival of the Chinese empire.

Indeed, nomadic states frequently threatened and twice conquered the entire empire. They could not match China's population, wealth, and technology, but they possessed a key military advantage in horse cavalry. While they were not centralized organizations like the Chinese state, nomad states were not at a disadvantage because they were financed not by taxing their people but by exploiting outside resources. In return for accepting subordinate political position, leaders of member tribes gained access to Chinese luxury goods and trade opportunities. As Barfield observes, those nomad empires enjoyed a positive synergy with the Chinese empire:

The stability [of nomad empires] depended on extorting vast amounts of wealth from China through pillage, tribute payments, border trade, and international reexport of luxury goods - not by taxing steppe nomads. When China was centralized and powerful, so were nomadic empires; when China collapsed into political anarchy and economic depression, so did the unified steppe polities that had prospered by its extortion. ${ }^{14}$

Although the nomads had much to gain by trading with the Chinese empire, the steppe had neither fertile land nor good climate to offer the empire's rice-growing farmers. The expansive and formidable Great Wall that various Central Plain rulers devoted substantial resources to build clearly testified about the enormous threat the nomads posed to them, but it also implied the lack of desire on the part of the Chinese empire to conquer and exploit the steppe.

As communities based on sedentary agriculture and ocean trade, mainland Southeast Asia seemed more attractive for the Chinese empire than the steppe on its northern frontier. The subtropical land and people on mainland Southeast Asia were more exploitable. The trading networks that linked Southeast Asia to South Asia and beyond were similarly desirable. However, the potential exploitability of mainland Southeast Asia for the Chinese empire did not quite measure up against other concerns and opportunities. I have mentioned the long distance from the Red River Delta to the Central Plain, which meant heavy costs for the empire to maintain permanent control over the Red River Delta. ${ }^{15}$

Yet costs were not the whole story; better and closer opportunities than the Red River Delta existed for Chinese expansion. Until the fourth century CE, the entire area of southern China today, from the Yangzi River to the Red River Delta, was still thinly populated.16 As China evolved, Han people from the Central Plain moved south in great numbers to search for new opportunities or simply to run from wars. ${ }^{17}$ Only by the Sui dynasty in the late sixth century did population density in southern China overtake that in the Red River Delta (Taylor 1983: 299-300). The vast area which is today's southern China thus absorbed most of the

14 Barfield 2001: 10. See a similar point in Holcombe 2001: 39.

15 These costs contributed to the generally hostile attitudes of the imperial elites toward the frontiers in the premodern period. See Woodside 2007: 16-22.

16 Sun Laichen even considers the whole area south of the Yangzi River in China as part of Southeast Asia. See Sun 2010: 44-79.

17 During the Eastern Han, for example, the Han Chinese population of northern China declined greatly due to natural disasters, diseases, and southward migration. Over two centuries as Han people fled to the South, nonHan groups moved in, making "the greatest population movement in [Chinese] history" (Hsu 20122: 189). 
expansive impulse of early China. ${ }^{18}$ By the late Tang period in the ninth century CE or so, now populous Guangdong could act as the commercial hub linking China with maritime Southeast Asia and beyond. From that point on, access to the Red River Delta became unnecessary for the Chinese empire as far as ocean trade was concerned.

A final difference between mainland Southeast Asia and the steppe along China's northern frontier was the possibility for the creation of a single empire on the steppe, which would be unthinkable for mainland Southeast Asia. Mainland Southeast Asia's population centers were scattered in several river deltas and along the coastal areas crisscrossed by high mountains. In such a difficult topography, the rise of a unified state would be extremely difficult, and indeed never occurred. ${ }^{19}$ As tribal societies consolidated into proto-states, mainland Southeast Asia came to be dotted by small and loosely organized polities based on agrarian and trading economies. These states fought each other regularly, and the number of autonomous states diminished over time due to conquests and annexations, but a unified state never emerged for the entire Southeast Asian mainland that could pose a threat to China's security. Together with other reasons, the absence of such a state implied that Chinese rulers had no compelling rationale to seek direct control over this region, especially if their northern frontier was under nomadic threat. In fact, as seen below, Chinese rule over the Red River Delta was first established not by any emperor but by a rebellious local Qin commander based in Guangdong.

\section{Premodern Đại Việt as a shadow empire}

By the time the Central Plain was unified under the Qin dynasty, neither bureaucratic states nor large urban centers existed anywhere in Southeast Asia (Hall 1992: 185). When the Han dynasty extended its rule to the Red River Delta about two thousand years ago, most native people believed to be the ancestors of the Vietnamese today still lived in the upland areas, northwest of the Red River delta and about 100 miles from the sea (Taylor 1983: 3; Whitmore 1986: 129). The river basins were still undeveloped. ${ }^{20}$ A Qin army first reached the Red River Delta around 214 BCE, but did not establish direct control over the area. When Qin collapsed, Zhao To, a Qin official in Guangdong, declared himself king over the southeastern frontier of the empire. Zhao fought back an invasion ordered by Han empress Lu. He soon acquired control over the Red River Delta and made it part of his newlyproclaimed Nan Yue Kingdom. After another Han army defeated Zhao's successor in 111 B.C.E., effective Chinese rule was established, not only over the Red River delta area (i.e. Jiaozhi/Giao Chỉ), but also over the northern part of central Vietnam today (Jiuzhen/Cửu Chân and Rinan/Nhật Nam). ${ }^{21}$

18 This is one of Victor Lieberman's main arguments that explain similar state formation patterns in Southeast Asia and Western Europe. See Lieberman (2011: 5-25).

19 Lieberman (2003: 27-28) also makes this point. Scott (2009) argues that this topography makes it difficult for low-land states to control and govern people in the highlands ("zomia"), but my argument here is about the difficulty to form a single state among various polities.

20 Hall 1992:188. For a perceptive examination of the Yue/Việt identity and its representations in early Chinese sources, see Brindley, Ancient China and the Yue.

21 For a discussion of the conquest of the Red River Delta in the context of imperial expansion under Qin and Han dynasties, see Chang 2007, v. 1: 52-53. See also Brindley 2015: 92-101. 
The imperial government was based in the area around Hanoi today, in the middle of the Red River delta. Over time, Han migrants intermarried with native people and created a distinct Han-Viet group in the delta. This group may have spoken a version of Middle Chinese together with a language called Proto-Viet-Muong that was predominant among native lowland population (Taylor 2013: 5, 25). From this group emerged many powerful families or kin groups which participated in the imperial administration and dominated local governments.

Imperial rule faced many revolts not only in Giao Chỉ, but all over the Southern frontier (Guangxi, Cửu Chân, and Nhật Nam). In the second century CE, a new Indianized kingdom called Lin-yi in Chinese sources was founded in Nhật Nam on the southernmost border of the empire. From then on Lin-yi became "the chronic adversary" for Red River delta inhabitants, probing, plundering, and appropriating territories in the frontier districts of the empire (Taylor 2013: 28). During the sixth and seventh centuries, Lin-yi was absorbed by other Indianized polities further south, ${ }^{22}$ but the threat remained. Raids on Giao Chi came from as far as the Java-based Sailendra kingdom. The ninth century saw the rise of Nanzhao, a Tai kingdom located in today's Yunnan and a tributary state of the Tibetan empire. Nanzhao posed a major threat to Tang rule throughout Guangxi, Guangdong, and Giao Chỉ (Backus 1981).

Above was the violent context confronting the inhabitants of the Red River Delta under imperial rule. Table 1 below lists the known revolts and conflicts involving Red River Delta and other peripheral polities along the Chinese frontier on mainland Southeast Asia. Many anti-imperial revolts were recorded in the 1,000 years during which Giao Chỉ was under northern rule, but they accounted for only a fraction of the period. At the same time, there were many conflicts between Red River Delta people and other frontier groups. Ever since the rise of Lin-yi in the late second century, and likely even before that, Giao Chi people had been exposed to the threat from those groups.

22 These were called Hwan-wang and Funan in Chinese sources. 
Table 1: Patterns of conflict in the Red River Delta under Chinese rule (219 BC-938 AD)

\begin{tabular}{|c|c|c|}
\hline $\begin{array}{l}\text { Dynasty or } \\
\text { Period }\end{array}$ & $\begin{array}{l}\text { Viet revolts against Chinese rule or war among frontier polities } \\
\text { on China's southern frontier }\end{array}$ & $\begin{array}{l}\text { Years } \\
\text { of } \\
\text { revolts }\end{array}$ \\
\hline \multicolumn{3}{|l|}{$\begin{array}{l}219 \text { BCE: Giao } \\
\text { Chỉ est. }\end{array}$} \\
\hline $\begin{array}{l}\text { 207-111 BCE: } \\
\text { Triệu dynasty } \\
192 \text { CE: Linyi } \\
\text { (Lâm Âp) est. }\end{array}$ & $\begin{array}{l}\text { 207-196 BCE, 185-180 BCE, 115?-111 BCE } \\
\text { 40-43 CE: Trưng sisters } \\
\text { 100: Nhật nam } \\
\text { 137: Khu Liên } \\
\text { 144 Cửu Chân } \\
\text { 157: Chu Đạt } \\
\text { 178-182: Lương Long }\end{array}$ & $\begin{array}{l}22 \\
4 \\
1 \\
2 \\
1 ? \\
1 ? \\
4\end{array}$ \\
\hline $\begin{array}{l}192 \text { CE: Linyi } \\
\text { (Lâm Âp) est. }\end{array}$ & $\begin{array}{l}\text { 245-248 Lady Triệu } \\
\text { 248: Linyi's victory } \\
\text { 263-271: Lữ Hưng }\end{array}$ & $\begin{array}{l}4 \\
1 \\
7\end{array}$ \\
\hline \multirow{5}{*}{$\begin{array}{l}\text { Funan (Phù } \\
\text { Nam) emerged }\end{array}$} & 344, 347: Linyi's attacks on Giao Chỉ & $?$ \\
\hline & $\begin{array}{l}\text { 468: Lý Trường Nhân } \\
\text { 542-547: Lý Bí } \\
\text { 543: Lý Bí fought Linyi } \\
\text { 571?-603: Lý Phật Từ }\end{array}$ & $\begin{array}{l}1 \\
6 \\
32 ?\end{array}$ \\
\hline & Chenla annexed Funan & \\
\hline & $\begin{array}{l}\text { 650?: Linyi (Hoàn vương) annexed by Chenla } \\
\text { 685-687: Lý Tử Tiên } \\
\text { 722: Mai Thúc Loan } \\
\text { 767: Sailendra's raid } \\
\text { 791-798?: Phùng Hưng } \\
\text { 819-820?: Dương Thanh } \\
\text { 862-865: Nanzhao's invasion }\end{array}$ & $\begin{array}{l}2 \\
? \\
1 \\
8 ? \\
3 \\
3\end{array}$ \\
\hline & 938: Ngô Quyền's victory over Southern Han & 1 \\
\hline
\end{tabular}

Broadly speaking, a positive synergy existed between the northern empire and Giao Chi. When the empire was strong, Giao Chỉ was at peace. When the empire was weak, broken, or preoccupied by other issues, Giao Chỉ was, following a lag period, frequently in turmoil. Part of the disorder was caused by local efforts to assert autonomy or independence. The revolt by the Trưng sisters took place in the early and chaotic years of the Eastern Han dynasty. The pattern was repeated with Lý Bí in the mid-sixth century, Mai Thúc Loan and Phùng Hưng in the late eighth century, and Ngô Quyền in the tenth century-all periods of great instability in the empire.

Nationalistic historiography has touted these revolts as evidence of the existence of "Vietnamese" people's exceptional passion for independence. Yet there are other more plausible explanations, if one takes into account the fact that the Red River delta people, prior to developing their own ability to self-rule, did not have a single identity nor even spoke a single language (Taylor 2014: 4-5). They often had to choose whether being imperial subjects or being ruled by other polities on the frontier. Revolt against the empire was not an 
automatic action in many cases. As Keith Taylor describes the dynamic of center-local interaction under Han dynasty that may well have applied for other periods:

In spite of the many shortcomings of the Han regime in [Giao Chỉ], it was nonetheless remarkably stable for nearly a century. When Han power began to decline, the first symptom in the south was not rebellion, but rather a deteriorating frontier. A series of invasions and frontier uprisings strained the administration beyond its capacity; this stimulated internal unrest and encouraged a spirit of insubordination (Taylor 1983: 59).

The dynamics of the revolts suggested that the Han-Viet families that ruled Giao Chi under the Han dynasty did not rise up to challenge imperial rule because they desired independence. More likely, they were forced to fend for themselves as the empire was descending into chaos after a long period of stability.

Nationalist historiography similarly cannot explain the failure of Giao Chỉ people to cooperate with other frontier groups to challenge northern rule. If these people had been so antagonistic toward the empire, they must have banded together against the big bully to the North. There were in fact attempts at cooperation which ended in failure. One was the revolt led by Mai Thúc Loan in 722 CE under Tang rule. This self-named "Black Emperor" was from Hoan prefecture, which was located on the edge of the imperial frontier adjacent to Linyi. Mai Thúc Loan rallied people from "thirty-two provinces" and from as far south as the Mekong delta and took brief control of Giao Chỉ, now called An Nam Protectorate. The revolt was supported by anti-Tang sentiments in the Protectorate but involved significant plundering activities which may have caused it not "to occupy a prominent place in the traditions of the Vietnamese people," in the words of Taylor (Taylor 1983: 192).

A more significant attempt at cooperation emerged during the Nanzhao war, which was one of the most prolonged and devastating wars during northern rule over Giao Chi. ${ }^{23}$ In this war, anti-Tang groups in Giao Chỉ cooperated with Nanzhao forces to expel the Tang governor from Giao Chi. But Nanzhao's brief rule, which was marked by plunder and violence, turned a large number of people into refugees hiding in caves and forests. Many Giao Chỉ people thus welcomed the return of Tang rule under Gao Pian whose army was sent to defeat Nanzhao forces. As Taylor notes, "[such Vietnamese efforts] to join with their neighbors against the Chinese failed in part because the Vietnamese realized that they could tolerate the avarice of their Chinese patrons more easily than they could the violence and unreliability of their non-Chinese allies." 24

Of course, over time, after each dynastic collapse in the north and each attempt by Giao Chỉ people to defend themselves during the ensuing chaos, they gradually became more confident of their own ability. This confidence accumulated just as imperial rulers became frustrated over time with all the troubles involved in maintaining control over the remote southern frontier. As Charles Holcombe argues, "[by the Tang dynasty], the Empire found it difficult and increasingly not worthwhile to project continuous effective administrative power into this awkward and remote salient" (Holcombe 2001: 162). That was how eventually Giao Chỉ became independent.

23 Taylor 1983: 239-49. See also Backus 1981: 135-45.

24 Taylor 1983: 194. Despite his perceptive and nuanced view of the relationship between the Han empire and Giao Chỉ as cited above, Taylor's first book published in 1983 still follows broadly the nationalist narrative. 
A final piece of evidence against the nationalist narrative is the fact that most revolts against northern rule were led or initiated by Han or Han-Viet imperial officials (Zhao To, Lũ Hưng, Lương Thạc, Lý Bí, and Ngô Quyền), not by ordinary native people with no links to the imperial government. There is no way to ascertain the motivations of those officials in launching such revolts, which certainly included elements of self-confidence as well as the need to defend themselves in times of imperial chaos. At the same time, one may wonder why they worked for the empire when it was strong and stable, but revolted only when it was disintegrating. Their revolts clearly had elements of opportunism (Holcombe 2001: 148-9, 157). Of course, when a new imperial dynasty was established, it would reassert its control, and the usurping officials would be punished. Zhao To's successor, Lư Hưng, Lương Thạc, and Lý Bí all ended up being chased away or killed by returning northern forces. Ngô Quyền escaped the fate of his predecessors not only because he was militarily more successful, but also because he arose at the time when the decline of the northern empire was not simply a dynastic affair, but a long term trend in which the empire was either divided or fell under one nomadic group after another for hundreds of years.

\section{Vietnam from self-rule to the modern era, 938-1884}

Ngô Quyền has been credited in official and nationalist Vietnamese history with ushering in the period of "Vietnamese" independence from "Chinese" rule. Yet the "Chinese" in that account was not the Tang emperor but Liu Yan (or Liu Gong), a regional warlord with royal pretensions who founded his kingdom on the southeastern frontier as the Tang empire collapsed. ${ }^{25}$ Viewed from the perspective of the frontier, $\mathrm{Ng} \hat{o}$ Quyền's emergence represented the continuity of a long-established pattern rather than a sharp break with the past as depicted in nationalist accounts. The collapse of the Tang once again forced the Han-Viet elites in An Nam to protect themselves against other groups on the frontier, of whom Liu Yan was not the only one. ${ }^{26}$

The Champa kingdom, a successor state to Lin-yi which emerged around the eighth century, had been a major threat to An Nam while it was still under Tang rule. Champa's regular raids for plunder and labor would continue to threaten An Nam/Đại Việt over the next seven centuries (Hall 1992: 259; Holcombe 2001: 159-60). The Darwinist survival-of-thefittest rule best described the relationship between Đại Việt and Champa, its archrival on the frontier. The history of this relationship was one of raids and counter-raids. After the fourteenth century Đại Việt emerged as the stronger party and sought to manipulate Champa's court politics. Eventually entire Champa was annexed into Đại Việt by the sixteenth century.

More threats for Đại Việt existed beyond Champa. Around the eleventh century, the powerful Khmer empire that built the Angkor complex emerged in the lower Mekong delta area. By the thirteenth century, the Mongols conquered Dali Kingdom (successor to Nanzhao), pushing many Tai communities further south. These communities soon created scattered Tai polities in the upper Mekong River and around the Chao Phraya River basins such as Lan Xang and Ayutthaya. 
Đại Việt's relationship with the Tai and Khmer kingdoms to its west was less brutal and did not end with complete annexation. Lan Xang (today's Laos) was protected from Đại Việt by natural barriers, and Đại Việt rulers were content with Lan Xang kings paying tributes. Another Tai polity named Bon Man was less fortunate and was annexed into Đại Việt at around the sixteenth century (Li 2010: 83-103). The Khmers did not come to share border with Đại Việt until the sixteenth century. Over the next two centuries, Vietnamese settlers in the eastern part of the Khmer kingdom enabled the Nguyễn lords of Đại Việt to claim sovereignty over that territory. While the Khmer kingdom retained its western part, it was reduced to Đại Việt's protectorate by the early nineteenth century (Chandler 2008: 142-61; Woodside 1971: 246-55).

The frequent conflicts Đại Việt had with other frontier states dwarfed the few wars it had with the Chinese empire, as Table 2 below indicates. To be sure, Ming emperor Yongle occupied Đại Việt for twenty years (1406-1428) with the intention of making it Ming's permanent territory. Viewed in the longer perspective, that seemed to be an isolated case. If the Song, Ming, and Qing had posed a constant threat to their survival, Đại Việt rulers would not have been able to devote that much energy to conquer and dominate other frontier states. In fact, it is possible to argue that an important factor in Đại Việt's successful conquests and annexations was the imperial tributary system that preserved peace and stability on Đại Việt's northern border so that it could turn all its attention southward. ${ }^{27}$ Đại Việt was not destined to dominate mainland Southeast Asia though. Li Tana argues that it was not until the fifteenth century when Đại Việt developed effective capacity to defeat Champa and Lan Xang (Li 2010). Sun Laichen believes that Đại Việt rulers were able to do so thanks in part to the military technology they borrowed from the north during the twenty years when Đại Việt was under Ming rule (1406-1428) (Sun 2010).

27 On Vietnam's tributary relations with China, nationalist historiography has depicted them as a means for Vietnamese to avoid Chinese invasion. Yet a study of envoy poetry by Liam Kelley shows that southern elites were genuinely proud of being part of the Sinic civilization. David Kang similarly argues that the tributary system was instrumental in preserving peace and stability in Chinese relationship with Korea, Japan, and Đại Việt. See Kelley 2005; Kang: 2010. 
Table 2: Patterns of conflict involving independent Vietnam (938 AD-present)

\begin{tabular}{|c|c|c|c|}
\hline $\begin{array}{l}\text { Dynasty or } \\
\text { Period }\end{array}$ & $\begin{array}{l}\text { Wars against } \\
\text { China (A) }\end{array}$ & $\begin{array}{l}\text { Wars among Viets or with frontier entities } \\
\text { or outside powers (B) }\end{array}$ & $\begin{array}{l}\text { Rough } \\
\text { ratio of } \\
\text { A/B }\end{array}$ \\
\hline $\begin{array}{l}\text { 938-944: Ngô } \\
\text { Quyền } \\
\text { 945-967: warlords } \\
\text { 968-979: Đinh Bộ } \\
\text { Lĩnh } \\
\text { 979-1009: Early } \\
\text { Lê dynasty }\end{array}$ & $\begin{array}{l}\text { 980: war with } \\
\text { Song }\end{array}$ & 982: Lê Hoàn's raid on Champa & $1 / 1 \mathrm{yr}$ \\
\hline $\begin{array}{l}\text { 1009-1224: Lý } \\
\text { dynasty }\end{array}$ & $\begin{array}{l}\text { 1075-77: war with } \\
\text { Song over border } \\
\text { control }\end{array}$ & $\begin{array}{l}\text { 1038-1052: Nùng rebellion } \\
\text { 1043-44: Viet's raid on Champa } \\
\text { 1069: Viet's raid on Champa }\end{array}$ & $3 / 16$ \\
\hline $\begin{array}{l}\text { 1225-1399: Trần } \\
\text { dynasty } \\
\text { 1350s: Lan Xang } \\
\text { (Laos) est. }\end{array}$ & $\begin{array}{l}\text { 1258, 1285, 1287: } \\
\text { wars with Mongols } \\
\text { 1282-84: Mongols' } \\
\text { invasion of } \\
\text { Champa }\end{array}$ & $\begin{array}{l}\text { 1292, 1294, 1297, 1334, 1335, 1346: Viet's } \\
\text { wars with Bo Man \& Lan Xang } \\
\text { 1312, 1318, 1326, 1352-53: Viet's raids on } \\
\text { Champa } \\
\text { 1366-68, 1371, 1377, 1378, 1383, 1389-90: } \\
\text { Champa's raids on Viet }\end{array}$ & $4 / 16$ \\
\hline $\begin{array}{l}\text { 1400-06: Hồ } \\
\text { dynasty } \\
\text { 1406-28: Ming's } \\
\text { occupation of Viet } \\
\text { 1428-1526: Lê } \\
\text { dynasty } \\
\text { 1527-92: Mạc } \\
\text { dynasty }\end{array}$ & $\begin{array}{l}\text { 1406: Ming's } \\
\text { invasion of Viet } \\
\text { 1407-13: Later } \\
\text { Trần revolt } \\
\text { 1418-1428: Lê } \\
\text { Lợi's revolt }\end{array}$ & $\begin{array}{l}\text { 1400, 1402, 1404: Viet's raids on Champa } \\
\text { 1427-32, 1437: Tai rebellions } \\
\text { 1479: war with Lan Xang } \\
\text { 1441, 1444, 1446, 1469, 1470-71: wars with } \\
\text { Champa } \\
\text { 1516-21: Trần Cao rebellion } \\
\text { 1545-92: Mạc-Trịnh war }\end{array}$ & $17 / 65$ \\
\hline $\begin{array}{l}\text { 1592-1786: Lê- } \\
\text { Trịnh } \\
\text { 1558-1777: } \\
\text { Nguyễn } \\
\text { 1786-1802: Tây } \\
\text { Sơn's rule } \\
\text { 1802-1945: } \\
\text { Nguyễn dynasty }\end{array}$ & $\begin{array}{l}\text { 1789: Tây Sơn } \\
\text { war with Qing }\end{array}$ & $\begin{array}{l}\text { 1627-1672: Trịnh-Nguyễn war (11 yrs) } \\
\text { 1653, 1692-4: raids on Champa } \\
\text { 1623, 1658, 1674, 1688-90, 1699-1700, } \\
\text { 1706, 1717, 1747, 1753, 1755, 1757: wars } \\
\text { with Khmer kingdom } \\
\text { 1740-51:Large peasant rebellions } \\
\text { 1771-1802: Tây Sơn-Trịnh-Nguyễn war } \\
\text { 1784: Tây Sơn war with Siam } \\
\text { 1858-84: war with France }\end{array}$ & $1 / 67$ \\
\hline $\begin{array}{l}\text { 1884-1945: } \\
\text { French colonial } \\
\text { rule } \\
\text { 1945-1975: DRV } \\
\text { 1949-1975: RVN } \\
\text { 1976: SRV }\end{array}$ & $\begin{array}{l}\text { 1979-88: war with } \\
\text { China }\end{array}$ & $\begin{array}{l}\text { 1945-46: Civil war } \\
\text { 1959-75: Civil war \& DRV's war with Lao } \\
\text { royal government } \\
\text { 1965-73: DRV's war with the U.S. } \\
\text { 1970-75: DRV's war with Lon Nol } \\
\text { government } \\
\text { 1977-89: war with the Khmer Rouge }\end{array}$ & $9 / 29$ \\
\hline Total & & & $35 / 194$ \\
\hline
\end{tabular}

Sources: Taylor (2013); Lê Mạnh Hùng, 'Nhìn Lại Sử Việt' [Re-examining Vietnamese History], vols. 1, 2 \& 3 (Arlington, VA: Tổ Hợp Xuất Bản Miền Đông Hoa Kỳ, 2012)

Table 2 shows that, while the Middle Kingdom remained the hegemon in the region, it was never the only, or even the most frequent, concern for Đại Việt. After Ngô Quyền, every Vietnamese dynasty spent more time attacking or coping with raids from further south and 
sometimes west, than dealing with the northern empire. One would miss much of the picture if neglecting the frontier context facing Đại Việt rulers.

Besides aiding Đại Việt indirectly, Chinese regimes also offered direct protection for those Việt elites who sought it to cope with threats from other Việt elites. A particular pattern of domestic conflict among the elites in Đại Việt that sometimes involved the Chinese empire was between the elites based in the Red River Delta and those whose base of power was in Thanh Hóa in north central Vietnam or from further south. These rival elites obviously had partisan motivations for requesting Chinese protection and assistance, although their claims were often made on the basis of communal interests or Heaven's mandate.

For example, descendants of Trần kings asked the Ming emperor for help after they were dethroned by Hồ Quý Ly in 1400. Hồ came from Thanh Hóa and it was not a coincidence that he moved the capital there rather than relying on the Red River Delta's elite which was still loyal to the Trần dynasty (Whitmore 1985: 44-5). Nearly two centuries later, in late sixteenth century, the Ming court intervened again to protect the Mạc rulers after they had been defeated and expelled from their power base in the Red River Delta by the Thanh Hóabased Trịnh lords (Taylor 1998: 957). The pattern was repeated in late eighteenth century when the Tây Sơn warlords from the area which is today's south central Vietnam marched into the Red River Delta and threatened the rule of King Lê Duy Khiêm (a.k.a. Lê Chiêu Thống). The King's mother requested intervention by the Qing Emperor, who sent in an army from Guangdong (Taylor 2013: 378). Lê Duy Khiêm was not a lone monarch representing a hated dynasty but had significant support from the elites in the Red River Delta.

By the seventeenth century, the southern frontier of the Chinese empire had attracted several European powers. The Dutch and the French played not insignificant roles in the civil wars between Trịnh, Nguyễn, and Tây Sơn lords (Taylor 2013: 290-5). In the face of the rising threat from the French in the mid-nineteenth century, Chinese protection was again called for. Nguyễn rulers begged Beijing for help, only to see China humiliated at the hands of the French (Brocheux and Hemery 2009: 43-6). Nationalist historiography in Vietnam today portrays Chinese interventions as "foreign invasions" while ignoring the inconvenient fact that many such invasions came from the requests of a significant component of Vietnamese elites.

The above examples suggested that Đại Việt rulers' behavior toward the North exhibited dependency in times of crisis when their power and privileges were threatened by their domestic enemies. In contrast, at times when their power was rising, some rulers boldly expressed their own imperial ambitions. The Lýs invasion of Nanning in 1075-1077 was such an occasion. At the time, the power of Đại Việt was rising while that of the Song dynasty was ebbing. Song rulers were besieged on three fronts by nomadic empires: the Liao empire of the Khitans, the Hsia empire of the Tanguts in the northwest, and the Jurchen empire of the Jin on the northeast (Rossabi 1983: 1-13). Militarily weak, Song was forced to pay tribute to all three in return for peace. Song did not threaten at all the survival of Đại Việt, but Lý monarchs wanted to expand their control over the northeastern frontier and retake territories from the tribes along the border that had recently switched their loyalty to the Song emperor (Anderson 2007). Nationalist narratives present the Lýs raid on Nanning as a preemptive attack in anticipation of a Chinese invasion, but earlier Đại Việt had in fact sought to challenge Song superiority in the border area. The fact that the attack was launched 
deep inside imperial territory suggested the unambiguous ambitions of Lý monarchs as they saw an opportunity to take on the northern giant.

Another example of imperial ambitions involved Nguyễn Ánh, the man who founded the Nguyễn dynasty. By the mid-eighteenth century, Đại Việt had fully annexed Champa and was providing “protection” to Chenla (today’s Cambodia) (Taylor 2013: 413-5). Đại Việt’s southern border had reached the southern tip of the Indochinese peninsular. After frequent warfare with Lan Xang to the west and Chenla to the southwest, Đại Việt's western frontier had expanded far enough to pose a direct threat to Siam (today's Thailand). Nguyễn Ánh had just defeated the Tây Sơn warlords and established a single government over the nowexpanded country for the first time. In 1802, after coming to the throne, Ánh sent an emissary to Beijing asking to acknowledge his new country under the name Nan Yue (Nam Việt).

Ánh's intention in choosing this name was to show that his new realm was different from and much larger than its predecessors. As Liam Kelley argues, "[u]ltimately, the name Việt Nam is related to the Nguyễn clan's southward expansion of the Lê Dynasty realm. What it signifies is that the Nguyễn created and ruled over something bigger than An Nam. It is a recognition of imperial expansion." ${ }^{28}$ To the Qing emperor and his advisors, the name recalled Nan Yue (207-111 BCE), the kingdom founded by Zhao To, that included Guangxi and Guangdong. Suspicious of Ánh's motives, they rejected his request. Yet Ánh insisted and threatened to cut off relations if the name was not accepted (Baldanza 2016). Eventually the Qing proposed Yue Nan (Việt Nam), a compromise which Ánh accepted.

Similar to the centuries when Giao Chỉ was under northern rule, as an independent kingdom Đại Việt enjoyed a positive synergy with the Chinese empire in the sense that a stable empire in the north allowed Đại Việt to direct all its energies against its frontier rivals. The history of this period shows that the Chinese empire was generally a benevolent big brother of Đại Việt except in two situations: the empire was either too weak or two strong. When it was too weak (late Song), it fell under nomadic rulers (Mongols) who sought to dominate Đại Việt. When the empire was too strong (Ming), Chinese rulers themselves sought to subjugate Đại Việt. These were the only conditions under which "China" may have threatened the survival of "Vietnam."

\section{Modern Vietnam as a shadow hegemon}

The international order in East Asia underwent violent ruptures for much of the nineteenth and twentieth centuries. European powers rolled back Chinese hegemony and eventually helped destroy the Chinese empire. European colonialism conquered territories just like traditional empires, but claimed a different kind of civilizing mission based on Judeo-Roman values. These empires, including the Japanese empire, all fell apart at the end of World War II, eventually replaced by nation-states. However, it is not difficult to observe many contemporary parallels of the old imperial order in East Asia.

The widespread acceptance of national self-determination as principles governing international relations has made imperial conquests rarer. Nevertheless, traces of imperial domination persist. During the Cold War, the Soviet Union and the United States backed rival

28 Personal communication. See also Kelley 2005: 114-6. 
ideological regimes in the region. The civilizing mission for the communist camp was the spread of Marxist-Leninist proletarian class struggle; that for the U.S.-led camp was Western capitalism and democracy. ${ }^{29}$ Communist China was at first a secondary power to the Soviet Union, but rose to challenge it in the 1960s (Chen 2001; Radchenko 2009). Since then, China has reemerged as a regional hegemon, battling Soviet and American influences in the region through its own client communist regimes or factions within ruling parties. ${ }^{30}$

Granted, new states from Indonesia to China are more centralized regimes than the traditional empires that preceded them. However, imperial patterns of behavior were apparent in the process by which they were formed. The reunification of China was quite similar to the traditional process of imperial making: the Republican and later communist armies established their rule through step-by-step military conquests of territories controlled by their rivals. Taking advantage of faltering colonial empires, Indonesia attempted to annex Malaysia in 1963 (unsuccessfully) and East Timor in 1975 (successfully for two decades). Similarly, communist parties in North Vietnam, Laos, and Cambodia successfully expanded their control through military conquests. In the process North Vietnam not only annexed South Vietnam but also gained great influence over Laos and Cambodia. For decades, a sizable Vietnamese force was stationed in Laos, and for a decade in the 1980s, Vietnam was the behind-the-scene ruler of Cambodia. ${ }^{31}$ Thus, the evolution of the regional order in East Asia has not completely departed from the era of traditional empires and shadow empires. Indeed, the boundaries of most new states have not changed much from the early modern imperial era. Even though empires no longer exist, they appear to have morphed into hegemons and shadow hegemons.

Below I will take a closer look at the evolution of modern Vietnam as a shadow hegemon. ${ }^{32}$ In the modern period, China played an important role in Vietnam, but other states along the violent frontier were just as important. Except for the decade of the 1980s, China was in fact the protector, not the bully, of Vietnam. China's assistance was crucial for Vietnam to achieve its hegemony over Indochina and beyond. As in the case with premodern Đại Việt, not just survival needs but the ambitions of some Vietnamese leaders were a key factor that drove the modern hegemonic project.

The nationalist movement emerged in Vietnam at the turn of the century, aiming to gain independence from French rule. To Vietnamese nationalists, France was the threat to Vietnam's survival as a nation, while other countries, including China, Japan, and the United States, were allies. ${ }^{33}$ Among anticolonial groups, Vietnamese communists came late on the scene but embraced a distinctively radical vision. In their thought, Vietnam and all other colonized and semi-colonized countries shared the threat of imperialism (Huynh 1982; Vu 2017, chapter 1). French colonialism was merely a component of global imperialism, and the fate of Vietnam was to be decided in part in the proletariat's global struggle against

\footnotetext{
29 See Westad 2010.

30 On Sino-Soviet relations in the 1970s and 1980s, see Chen 2001; Whiting 1984: 142-55. For more recent situation, see Sutter 2005; Shambaugh 2005; and Storey 2011.

31 For a similar view of Indonesia and Vietnam as regional hegemons, see Emmer 2005: 645-66. On Vietnam's occupation and hegemony over Cambodia in the 1980s, see Clayton 1999: 341-63; Clayton 2000: 109-24.

32 I acknowledge the French contribution to the hegemonic position of Vietnam in Indochina today but do not dwell on colonial legacies due to space constraint. For the seminal work on this topic, see Goscha 2012. 33 A standard survey of this period is Marr 1981.
} 
capitalism and imperialism. In that struggle, Vietnam had to confront not just foreign imperialist powers but also domestic reactionary classes. These classes posed as much a threat to Vietnam's road to socialism as did their foreign backers.

The communists embraced both national and class identities (Huynh 1982). To them, the bonds among peasants and workers across national borders were just as salient as the distinctions between Chinese, Khmers, Vietnamese, Laotians, and Thais. It was thus appropriate that the Comintern agent Lý Thụy (a.k.a. Hồ Chí Minh) participated in the social revolution in southern China, organized ethnic Vietnamese in northeastern Siam, and assisted in the founding of the Siamese and Malay communist parties (Quinn-Judge 2002, esp. 86-9; Goscha 1999). By the late 1940s, when Hồ Chí Minh led the Democratic Republic of Vietnam (DRV) in a war against France, the secret Indochinese Communist Party had many Laotian and Cambodian members besides Vietnamese ones (Englebert and Goscha 1995).

France was the main threat to Vietnam then, and China played little role in the struggle (except for a brief period during 1945-1946 when Nationalist China stationed troops in North Vietnam to disarm Japanese forces). ${ }^{34}$ This soon changed. After Chinese communists took control of mainland China in 1949, the DRV quickly turned to them for protection and assistance. ${ }^{35}$ Vietnamese communists enthusiastically accepted the ideological and policy guidance from Soviet and Chinese communists, enshrining Stalin and Mao Zedong Thought in the party constitution. Hundreds of children of top government leaders were sent to China and later to the Soviet Union for education (Hồ 2004). At the same time, Chinese advisors labored to reorganize the Vietnamese communist party along class line and to launch a radical land reform (Qiang 2000, chapter 1). In the imagination of Vietnamese communist leaders, Vietnam had become the "outpost" of the socialist bloc centered in Moscow. This bloc acting through China offered great assistance to communist Vietnam in the anti-French war as well as protected it from possible American intervention.

At Geneva in 1954, the DRV accepted a temporary border on the $17^{\text {th }}$ parallel in return for French withdrawal from Vietnam. ${ }^{36}$ This line of demarcation would soon become a fortified border dividing North Vietnam from the South where an anticommunist regime was established in Saigon with the backing of the U.S. and its Southeast Asian allies. The Geneva Agreements also committed the DRV to suspending their support for communist revolutions in Laos and Cambodia and to acknowledging the independence of royal governments there (Asselin 2007: 95-126).

After deciding in 1959 to launch the war against the Republic of Vietnam (RVN) in South Vietnam to gain control of the entire country, the DRV resumed support for Lao communists, paving the way for a client communist state there (Goscha 2004: 141-85). In Cambodia, the DRV tried throughout the 1960s to maintain good relations with the Sihanouk regime while offering some support to Cambodian communists (Englebert and Goscha 2004: 101-70; Morris 1999, chapter 1). When Lon Nol overthrew King Sihanouk in 1970, the DRV gave Cambodian communists all the support it could muster. They now shared the same goal of overthrowing "imperialist" rule in Phnom Penh and Saigon, which they achieved in April 1975 .

34 See Tønnesson 2010).

35 Qiang 2000: 10-20. See also Goscha 2000: 987-1018; and Nguyễn 2013: 53-5.

36 The best account of this event is Asselin 2013. 
Throughout the period above, some tension existed between the DRV and its Chinese protector, but China was never a threat. Rather, the primary threat was the U.S. and its Asian allies, including the Saigon regime. By 1975, communist Vietnam dominated Indochina (Chanda 1986). Lao leaders appeared content, but top Cambodian communists like Pol Pot who had long resented Vietnamese domination were about to challenge Vietnamese hegemony. Vietnam may have permitted Cambodia to go its own way if it did not threaten Vietnam. When Pol Pot and his Cambodian comrades did so with the support of a hostile China, Vietnam responded with an invasion of Cambodia. ${ }^{37}$

Initially the invasion appeared to have been the last resort by Vietnam to cope with a serious Cambodian and Chinese threat. With the success of the invasion, Hanoi then took the opportunity to occupy Cambodia for a decade (Chanda 1986). During 1978-1988, as Vietnamese occupation of Cambodia continued, China was an enemy and threat to Vietnam-for the first time in the modern era. Vietnam's hegemonic ambitions were challenged not only by China and Cambodia, but also by nearly all Southeast Asian states along the southern frontier of China. These states collaborated through the Association for Southeast Asian Nations (ASEAN) to support the deposed Khmer Rouge in their protracted fight against Vietnam's domination (Ciorciari 2010: 72-83).

As in the premodern period, modern Sino-Vietnamese conflict turned out to be relatively brief compared to the periods of peace and collaboration between the two communist states. By the late 1980s, as the Soviet bloc collapsed, Vietnam suddenly found itself threatened by imperialism. While Vietnamese leaders admitted that Beijing was chauvinist, it was nonetheless a socialist regime that Hanoi could count on as one of a few communist allies left on earth. ${ }^{38}$ That was how Beijing became Hanoi's comrade again, for the following two decades. Not until in the last few years did Sino-Vietnamese relations take a bad turn and became tense ( Vu 2014: 33-66). Many Hanoi leaders still feel the need for Chinese protection against imperialist plots to subvert the regime. Of course, they claim that Vietnam has no future but socialism, and for that to happen, comradeship with socialist China is not only rational but also necessary. ${ }^{39}$ Nevertheless, it is clear that regime survival, not national survival, is at stake.

37 For a recent study, see Westad and Quinn-Judge (eds) 2006.

38 Trần Quang Cơ, "Hồi Úc và Suy Nghî" [Memories and Thoughts] (July 2005). Trần Quang Cơ was a deputy foreign minister in the late 1980s. In explaining Vietnam's move to restore a closer relationship with China, David Elliott considers security as the primary factor, arguing that, "without the Soviet Union as a counterbalancing superpower patron Vietnam could not afford to persist in its open defiance of its giant neighbor, China. In addition, ... Vietnam [needed] to preserve some elements of the old "fraternal friendship" among socialist countries [especially with an important country like China] in order to validate its own continued adherence to Marxism-Leninism as the central organizing principle of its political regime" (Elliott 2012: 88). However, the fact is that Vietnam had already wanted to restore relations with China since late 1986 after Le Duan's death when the Soviet Union was still around. Furthermore, restoring relations was totally different from proposing to form an anti-imperialist alliance with China, which suggested that ideology rather than security was the primary factor. Vu 2017, esp. 249, 252.

39 On Hanoi leaders' pledge to be loyal to socialism, see the Vietnamese Communist Party's latest program: "Cuong linh xay dung dat nuoc trong thoi ky qua do len Chu nghia xa hoi" [Program to build the country in transition to socialism] (March 2011). Available at http://123.30.190.43:8080/tiengviet/tulieuvankien/vankiendang/details.asp?topic=191\&subtopic=8\&leader_t opic=989\&id=BT531160562. On the general attitude of a top Vietnamese leader toward China, see Minister of Defense Gen. Phùng Quang Thanh's uncanny comment on December 29, 2015 that "the inclination to hate 
Since the 1990s, Vietnam has turned inward to revive its economy and society exhausted after decades of war and mistaken socialist policies. Vietnam's hegemony over Indochina has weakened significantly and may end in the future. Despite that uncertainty, it should be clear by now the parallels between modern Vietnam as a shadow hegemon and the premodern Đại Việt empire. During the process by which the Vietnamese hegemon emerged, China played a prominent role as a protector, not a nemesis. Under China's protective umbrella even more than in the premodern past, Vietnamese communists turned south to expand their power, first all over Vietnam, then all over Indochina. To them, China was the guarantor of Vietnam's survival needs, and other states on the frontier were threats.

There is yet another interesting parallel between premodern Đại Việt and modern Vietnam: the imperial or hegemonic ambitions of some Vietnamese leaders. During the Vietnam War, as the American global hegemon fought with the Chinese regional hegemon, it appeared that Vietnam became the victim for being caught in the periphery between the two blocks. This is in fact the central theme of much nationalist historiography. Recently declassified archival documents show that it was not that simple. As seen below, Vietnamese communism depended heavily on Moscow and Beijing for support but that did not prevent ambitious Hanoi leaders from imagining themselves as the center of the camp.

In the early days, both Chinese and Vietnamese communists were sincere in their collaboration, which they viewed as a revolutionary brotherhood, not the old imperial or tributary relations. China, and later North Vietnam, also provided assistance to communist "brothers" in Burma, Thailand, Laos, Cambodia, Malaysia, and Indonesia (Lim and Vani 1984). The revolutionary brotherhood was supposedly based on egalitarian and proletarian internationalism, but it did contain an implicit hierarchy even in its early days. The Soviet Union, the birthplace of the first communist and most powerful state, occupied the leadership position. China, with its large territory and population, was second. Communist North Vietnamese ranked third for at least having control of a small state. Below these three were communist parties and movements elsewhere in the region which were still struggling to seize state power. Despite the implicit hierarchy, the brotherhood seemed to mark a fundamental departure from the old imperial days. Following Stalin's death, Khrushchev's controversial policies created schisms throughout the entire communist movement worldwide in the 1960s (Brzezinski 1967). In East Asia, China openly challenged Soviet leadership, forcing all peripheral communist parties to choose between the "Eldest Brother" and "Second Brother." 40 Mao's quarrel with Khrushchev and his leadership over the chaotic and violent Cultural Revolution dimmed his own prestige in Hanoi (Path 2011). Beijing attempted to create a new communist camp under its leadership but Hanoi refused to go along while continuing to receive material support from both China and the Soviet Union. ${ }^{41}$

As early as 1963, some Vietnamese leaders, most prominently Lê Duẩn, had displayed in private their contempt for Mao. In his meeting with Mao in mid-1963 in Beijing, Duẩn was said to have been offended when Mao declared his willingness to take his army south to help

China is dangerous for the [Vietnamese] nation." See http://www.hoangsa.org/f/threads/xu-th-ghet-trungquc-nguy-him-cho-dan-tc.1556/ [original article on official website thanhtra.gov.vn has been removed].

40 For a recent account of the topic, see Luthi 2008.

41 See Trần Quỳnh, "Mấy kỷ niệm về Lê Duẩn" [Memories about Lê Duẩn]. Trần Quỳnh was Chief of Staff of the Central Party Office and a confidante of Le Duan. 
liberate Southeast Asia. ${ }^{42}$ Duẩn's sentiment can be interpreted not only as reflecting Vietnamese ancient fears of Chinese domination, but also as a sign of rivalry between the two leaders. On the same occasion, Duẩn was reportedly scornful of Mao's claim that the landlords were back in power in China by marrying off their daughters to village cadres. ${ }^{43}$ Duẩn also expressed contempt for Chinese communists' theoretical ability and revolutionary experience on other occasions. He repeatedly, if obliquely, belittled Chinese revolutionary experiences in his political reports. He ridiculed the legendary Chinese Long March by calling it the strategy of "running around" [truờng chinh chay quanh] instead of confronting the enemy. ${ }^{44} \mathrm{He}$ dismissed Mao's theory of three stages in guerrilla warfare as irrelevant and inferior to his own strategy of "three kinds of forces." 45 On the eve of the Tet Offensive in 1968, Duẩn told the Central Committee that,

Had we just copied [foreign models] we would not have won the war [thus far] against half a million American troops. [Our strategy] is different from and even contrary to Chinese and Soviet [models].... Recently I talked to some Chinese comrades that our units in the delta were no larger than two combined battalions but were able to destroy one whole American battalion. In one case four of our soldiers attacked nine American warships armed with 100 big guns. Those [Chinese] comrades had no clue...Four soldiers did the job of a division and suffered no casualties - how strange [it was to them]! ${ }^{46}$

With the daring communist attacks in the Têt Offensive in South Vietnam, the international prestige of Vietnamese communism soared at the same time as world opinion turned dramatically against the U.S. ${ }^{47}$ Earlier Vietnamese leaders had thought of themselves as merely occupying an outpost of the socialist bloc. Now they began to imagine themselves as being on the frontier and the vanguard of world revolution. On the Anniversary of Karl Marx's $100^{\text {th }}$ birthday in May 1968, Trường Chinh wrote that "Vietnam is proud of leading the [global] offensive against imperialism. Because the U.S. is using Vietnam as a laboratory for all of its war strategies and modern weapons, the world's people have much to learn from Vietnam how to defeat those strategies and weapons." 48

After the Paris Agreements, Hanoi became overwhelmed with pride. Lê Duẩn went so far as dismissing China as a hegemon in a speech to high-ranking cadres in 1974: "The Chinese revolution was a big event because it brought a quarter of mankind into socialism, but essentially it was a civil war to solve internal antagonisms in Chinese society. Vietnam is a

42 Ibid. Also, "Le Duan and the Break with China" 2001: 281.

43 Landlord status is theoretically defined by ownership of land and the hiring of labor, not by marital relationship.

44 See "Bai noi cua dong chi Le Duan ... tai Hoi nghi lan thu 12 cua Trung uong" [Comrade Le Duan's speech at the $12^{\text {th }}$ Central Committee Plenum], December 1965. Dang Cong San Viet Nam, Van Kien Dang Toan Tap (hereafter VKDTT), v. 26 (Hanoi, Chinh tri Quoc gia, 2002), 597.

45 This referred to the organization of revolutionary forces in three different terrains: division-level main forces for the mountainous regions, battalion-level forces for the delta, and militias for urban centers.

46 "Bai noi cua dong chi Le Duan tai Hoi nghi Trung uong lan thu 14" [Comrade Le Duan's speech at the $14^{\text {th }}$ Central Committee Plenum], January 1968. VKDTT v. 29, 19.

47 See Turley 2009: 137-58.

48 Truong 1968: September 1968, 1-12 and October 1968, 10-27, 45-52. 
small country, but in our war against the Americans, our country has become the place that embodies all the fundamental antagonisms of the world." 49

The victory in 1975 brought to communist Vietnam the greatest admiration from its fans and greatest fear from its foes. Hanoi leaders began to speak in language befitting a hegemon. In his speech at the Party's $25^{\text {th }}$ Central Committee Plenum in late 1976, Lê Duẩn boasted:

Our victory over imperialist America created conditions for Laotian and Cambodian revolutions to triumph, opening the path to socialism for them. In the history of [world] proletarian revolution, thus far only the Soviet Union could liberate itself and some other countries [in the process]. It is a very special honor for Vietnam today to have performed that deed. ${ }^{50}$

In the fall of 1975, Lê Duẩn led a delegation to visit to Moscow and many Eastern European capitals to thank them for supporting Hanoi during the war and to ask for their continuing assistance. In Moscow, the Vietnamese delegation met with top Soviet leaders, where Duẩn requested a Soviet loan of one billion rubles for many projects. When Soviet leaders expressed their reluctance to fund his grand pet project, a steel plant worth 200 million rubles, Duẩn told them,

We are poor now, but it'll be different in five or ten years. We won't be this poor in ten years. When we fought the French, we had many difficulties. We never thought we would achieve victory as we have. Now [even] the U.S. has lost [to us]. Previously the Philippines was an American lackey but now its attitude has shifted. The U.S. and Japan [now] want to control [Southeast Asia]. Our country may be small but we will defeat them with Soviet help. In peace we want to make Vietnam into the center of socialism in Southeast Asia. That's the direction of our political and economic policy. Southeast Asia with more than a hundred million people is a large area. In this region, besides Japan, no other country is [as powerful] as Vietnam. I mean socialist Vietnam... We have set the precondition that Thailand and the Philippines must expel the Americans from their countries in order to improve relations with Vietnam... 51

Duẩn asserted that Vietnam had fought selflessly for world revolution and therefore deserved Soviet help to achieve even more victories for socialism:

Up to now we have said that we were fighting to defend socialism and world peace and we were willing to shoulder all the losses. Now [the world] has peace, but socialism still needs to be defended. We want to achieve economic victory [besides military victory]. Who knows what will happen in 10, 15, 20 years? Perhaps thanks to our influence Burma and India will also change. Previously India supported the American war on Vietnam. Our Foreign Ministry wanted to sever diplomatic relations with India, but I counseled against that. [I said that,] when we achieved victory, India would

49 "Bài nói của đồng chí Lê Duẩn tại Hội nghị phổ biến Nghị quyết của Quân ủy Trung ương cho cán bộ cao cấp" [Comrade Le Duan's speech at the Conference to announce the Resolution of the Central Military Committee to high-ranking cadres], April 25, 1974. VKDTT v.35, 36.

50 "Phat bieu cua dong chi Le Duan tai Hoi nghi lan thu 25 cua Trung uong" [Comrade Le Duan's speech at the $25^{\text {th }}$ Central Committee Plenum]. The Plenum took place during September 24-October 24, 1976. VKDTT v. $37,344$.

51 "Bien ban Hoi dam giua Doan dai bieu Dang va Chinh phu Viet nam dan chu cong hoa va Doan dai bieu Dang va Chinh phu Lien Xo" [Memorandum of the Meeting between the delegation of the Party and government of the DRV and the Party and government of the Soviet Union], October 27-31, 1975, pp. 24-25. File 9735, Phu Thu Tuong, National Archive No. 3, Hanoi. 
change its attitude. After we won the war, India [came around] to help us... India thanked us because we had weakened the Americans. ${ }^{52}$

Duẩn failed to persuade the skeptical Soviets to approve his pet plant, but the statement revealed that his ambition was not only to defeat imperialism at war but also to showcase the economic superiority of socialism that could even convert gigantic India to the cause.

The fact that Vietnam was peripheral to the power centers of the world did not prevent Hanoi leaders to dream big. They eventually woke up to reality in the 1980s when Beijing was able to isolate Vietnam internationally and force Hanoi to pay a high price for that dream. Yet, as we have seen, Lê Duẩn and his comrades were not the first Vietnamese to hold imperial or hegemonic ambitions.

The modern era witnessed a colonized Vietnam rising up to reclaim its premodern status as the most powerful state on Indochina. During this period, China and Vietnam not only interacted with a positive synergy but became close brothers sharing an ideological vision and geopolitical interests for at least two decades (1949-1969). Clearly Vietnamese communists would not have been able to unify the country and dominate Laos and Cambodia without Chinese support. Even brothers sometimes quarrel, and the Sino-Vietnamese conflict during 1979-1988 was caused by a combination of diverging ideological visions, Hanoi's suspicion of and contempt for Beijing, and Chinese effort to expand its frontier into Southeast Asia by seizing the Paracels and by supporting the Khmer Rouge. Despite the conflict, China returned to being a benevolent big brother of Vietnam in the 1990s and 2000s. ${ }^{53}$

\section{Conclusion}

This paper examined Vietnam as a shadow empire and hegemon on the southern frontier of China. Nationalist historiography assumes an internally united Vietnam threatened by a united China, reduces complex Sino-Vietnamese relations to one single dimension of domination and resistance, exaggerates the importance of Vietnam to China while ignoring the importance of other frontier states for Vietnam, and overlooks Vietnamese ambitions to dominate China's southern frontier. Despite such serious shortcomings, the nationalist narrative has been wildly popular. Small Vietnam's location on the periphery of the giant Chinese empire gives that narrative an apparent basis in reality, while Vietnam's modern wars against France and the U.S. popularized it. Recent scholarship has challenged this standard historiography but is still preoccupied with dyadic Sino-Vietnamese interactions in which China and Vietnam are taken out of their broader geopolitical contexts and juxtaposed as opposites.

In contrast, I have used a comparative historical approach to show how premodern Đại Việt and modern Vietnam emerged and became a shadow empire and hegemon. As empire and hegemon Đại Việt or Vietnam was not in the same league with great powers such as China. Nevertheless, the process of imperial formation was similar, and the feelings of Vietnamese citizens of Cham and Khmer ethnic backgrounds toward Vietnam are perhaps not different from those Tibetans or Uighurs have toward China. The paper found that the

52 Ibid.

53 See Vu 2017, chapter 10. 
southern frontier was much less important for premodern Chinese rulers than its northern frontier. This affected Chinese relations with states on its southern border, including Vietnam.

Vietnamese conflicts with other frontier peoples were found to be far more frequent than those with China. Survival threats for Vietnamese have emanated more from within the frontier than from China. Throughout history, China has in fact been the patron of Vietnam more than an enemy or a threat. The relationship contained a positive synergy even when northern Vietnam was under Chinese rule, became a conditional positive synergy under Đại Việt, developed into an intimate brotherhood in the middle decades of the twentieth century, and has carried a positive synergy after the end of a conflict in the 1980s.

In light of the findings in this paper, some speculative remarks can be made about the future directions of the contemporary tensions in the South China Sea between China and Vietnam. One may draw a parallel between the Ming Emperor Yongle (1402-1424) and Chinese President Xi Jinping: both are leaders of a strong and ambitious China wishing to expand its frontier further south. A key difference between the Ming era and today is the presence of powerful states, namely India, Japan, and the United States, on China's southern frontier which can counterbalance China. Yet a Sino-Vietnamese war would be unlikely, for Vietnam currently has a weak regime and no ambitious leader like Nguyễn Ánh or Lê Duẩn. Despite rising tensions with China, a major faction within the Vietnamese leadership still look to Beijing for protection against real or imagined domestic and frontier threats, which range from rebellious farmers to brave democracy activists, and from subversive overseas Vietnamese groups to "hostile (Western) forces." The positive synergy that has underlined Sino-Vietnamese relations since the early 1990 s is likely to continue, albeit in a more muted form.

\section{References}

Anderson, James (2007), The rebel den of Nùng Trí Cao: Loyalty and identity along the SinoVietnamese frontier. Seattle: University of Washington Press.

Anderson, James (2013), "Distinguishing between China and Vietnam: Three relational equilibriums in Sino-Vietnamese relations," Journal of East Asian Studies 13: 259-280.

Anderson, James and John Whitmore (2015), "Introduction: The fiery frontier and the Dong World," in idem. (eds), China's encounters the south and the southwest: Reforging the fiery frontier over two millennia. Leiden: Brill.

Asselin, Pierre (2007), "Choosing Peace: Hanoi and the Geneva Agreements, 1954-1955," Journal of Cold War Studies 9, 2: 95-126.

Asselin, Pierre (2013), Hanoi's road to the Vietnam War, 1954-1965. Berkeley: University of California Press.

Backus, Charles (1981), The Nan-Chao Kingdom and T'ang China's southwestern frontier. New York: Cambridge University Press.

Baldanza, Kathlene (2016), Ming China and Vietnam: Negotiating borders in early modern Asia. New York: Cambridge University Press.

Barfield, Thomas (1992), The perilous frontier: Nomadic empires and China 221 B.C. to AD 1757. Cambridge, MA: Blackwell. 
Barfield, Thomas (2001), "The shadow empires: imperial state formation along the ChineseNomad frontier," in Susan Alcock et al., Empires: Perspectives from archaeology and history. New York: Cambridge University Press. Pp. 10-41.

Brindley, Erica (2015), Ancient China and the Yue: Perceptions and identities on the southern frontier, c. 400 BCE-50 CE. New York: Cambridge University Press.

Brocheux, Pierre, and Daniel Hemery (2009), Indochina: An ambiguous colonization 18581954, transl. Ly-Lan Dill-Klein. Berkeley: University of California Press.

Brzezinski, Zbigniew (1967), The Soviet bloc, unity and conflict. Cambridge, MA: Harvard University Press.

Chanda, Nayan (1986), Brother enemy: The war after the war. San Diego: Harcourt Brace Jovanovich.

Chandler, David (2008), A history of Cambodia, $4^{\text {th }}$ edition. Boulder: Westview Press.

Chang, Chun-Shu (2007), The rise of the Chinese Empire, v. 2. Ann Arbor: University of Michigan Press.

Chen Jian (2001), Mao's China and the Cold War. Chapel Hill: University of North Carolina Press.

Ciorciari, John D. (2010), The limits of alignment: Southeast Asia and the great powers since 1975. Washington, D.C.: Georgetown University Press.

Clark, Ian (2011), Hegemony in international society. New York: Oxford University Press.

Clayton, Thomas (1999), "Cambodians and the occupation: Responses to and perceptions of the Vietnamese occupation 1979-89," South East Asia Research 7, 3: 341-63.

Clayton, Thomas (2000), "The shape of hegemony: Vietnam in Cambodia, 1979-1989," Education and Society 18, 2: 109-24.

Cochran, Sherman, and Paul Pickowicz (eds) (2010), China on the margins. Ithaca: Cornell East Asia Program.

Di Cosmo, Nicola (2002), Ancient China and its enemies: The rise of nomadic power in East Asian history. New York: Cambridge University Press.

Doyle, Michael (1986), Empires. Ithaca, NY: Cornell University Press.

Elliott, David (2012), Changing worlds: Vietnam's transition from Cold War to globalization. New York: Oxford University Press.

Emmer, Ralf (2005), "Regional hegemonies and the exercise of power in Southeast Asia: A study of Indonesia and Vietnam," Asian Survey 45,4: 645-65.

Englebert, Thomas, and Christopher Goscha (1995), Falling out of touch: A study on Vietnamese Communist policy toward an emerging Cambodian Communist movement, 1930-1975. Melbourne: Monash University.

Gill, Stephen (1993), Gramsci, historical materialism, and international relations. New York: Cambridge University Press.

Goscha, Christopher (1999), Thailand and the Southeast Asian networks of the Vietnamese Revolution, 1885-1954. Surrey: Curzon Press.

Goscha, Christopher (2000), "The borders of Vietnam's early wartime trade with Southern China: A contemporary perspective," Asian Survey 40,6: 987-1018.

Goscha, Christopher (2004), "Vietnam and the world outside: The case of Vietnamese Communist advisers in Laos (1948-62)", South East Asia Research 12, 2: 141-85.

Goscha, Christopher (2012), Going Indochinese: Contesting concepts of space and place in French Indochina. Copenhagen: NIAS Press.

Hall, Kenneth (1992), "Economic history of early Southeast Asia," in Nicholas Tarling (ed.), The Cambridge history of Southeast Asia, v. 1. New York: Cambridge University Press.

Heder, Steve (2004), Cambodian Communism and the Vietnamese model, v. 1. Bangkok: White Lotus. 
Hồ Anh Dũng et al (eds) (2004), Lớn lên giũa Mạc Tu Khoa: Kỷ niệm 50 năm trương thiếu nhi Việt Nam Internat Moskva [Growing up in Moscow: The 50 ${ }^{\text {th }}$ Anniversary of Internat Moskva, the school for Vietnamese youths]. Hanoi: Thế Giới.

Holcombe, Charles (2001), The genesis of East Asia, 221 B.C.-A.D. 907. Honolulu: University of Hawaii Press.

Hsu, Cho-yun (2012), China: A new cultural history. New York: Columbia University Press.

Huynh Kim Khanh (1982), Vietnamese Communism 1925-1945. Ithaca: Cornell University Press.

Kang, David (2010), East Asia before the West. New York: Columbia University Press.

Kellerman, Aharon (2007), "Transitions in the meanings of frontiers: from settlement advance to regional development," Journal of Geography 96, 5: 230-4.

Kelley, Liam (2005), Beyond the bronze pillars: Envoy poetry and the Sino-Vietnamese relationship. Honolulu: University of Hawaii Press.

Kleinfeld, Judith (2012), The frontier romance: Environment, culture, and Alaska identity. Fairbanks: University of Alaska Press.

Lary, Diana (ed.) (2007), The Chinese state at the borders. Vancouver: UBC Press.

"Le Duan and the Break with China" [transl. by Chris Goscha]. Cold War International History Project Bulletin 12/13 (Fall/Winter 2001).

Li Tana (2010), "The Ming factor and the emergence of the Viet in the $15^{\text {th }}$ century," in Geoff Wade and Sun Laichen (eds), Southeast Asia in the fifteenth century. Singapore: NUS Press. Pp. 83-103.

Lieberman, Victor (2001), "South East Asia and Eurasia during a thousand year," South East Asia Research 19, 1: 5-25.

Lieberman, Victor (2003), Strange parallels: Southeast Asia in global context, c. 800-1830, v. 1. New York: Cambridge University Press.

Lim, Joo-Jock, and S. Vani (1984), Armed Communist movements in Southeast Asia. Aldershot, UK: Gower.

Lundestad, Geir (2012), The rise and decline of the American "Empire": Power and limits in comparative perspective. New York: Oxford University Press.

Luthi, Lorenz (2008), The Sino-Soviet split: Cold War in the Communist world. Princeton: Princeton University Press.

Maier, Charles (2006), Among empires: American ascendancy and its predecessors. Cambridge, MA: Harvard University Press.

Marr, David (1971), Vietnamese anticolonialism, 1885-1925. Berkeley: University of California Press.

Marr, David (1981), Vietnamese traditions on trial: 1920-1945. Berkeley: University of California Press.

Morris, Stephen J. (1999), Why Vietnam invaded Cambodia: Political culture and the causes of war. Stanford: Stanford University Press.

Nguyễn Thị Mai Hoa (2013), Các nước Xã hội chủ nghĩa ủng hộ Việt Nam kháng chiến chống Mỹ, cúu nước [Socialist countries' assistance to Vietnam's resistance against America to save the country]. Hanoi: Chinh tri Quoc gia.

Path, Kosal (2011), "Hanoi's response to Beijing's renewed enthusiasm to aid North Vietnam 1970-1972," Journal of Vietnamese Studies 6, 3: 101-39.

Qiang Zhai (2000), China and the Vietnam Wars, 1950-1975. Chapel Hill: University of North Carolina Press.

Quinn-Judge, Sophie (2002), Ho Chi Minh: The missing years 1919-1941. Berkeley: University of California Press.

Radchenko, Sergey (2009), Two suns in the heavens: The Sino-Soviet struggle for supremacy, 1962-1967. Washington, D.C.: Woodrow Wilson Center. 
Rossabi, Morris (1983), "Introduction," in China among equals: The Middle Kingdom and its neighbors, $10^{\text {th }}$ to $14^{\text {th }}$ century. Berkeley: University of California Press.

Schroeder, Paul (2009), "From hegemony to empire: The fatal leap," in I. William Zartman (ed.), Imbalance of power: US hegemony and international order. Boulder, CO: Lynne Rienner Publishers.

Scott, James (2009), The art of not being governed: An anarchist history of upland Southeast Asia. New Haven: Yale University Press.

Shambaugh, David (ed.) (2005), Power shift: China and Asia's new dynamics. Berkeley: University of California Press.

Storey, Ian (2011), Southeast Asia and the rise of China: The search for security. New York: Routledge.

Sun Laichen (2010), "Assessing the Ming role in China's southern expansion," in Geoff Wade and Sun Laichen (eds), Southeast Asia in the fifteenth century: The China factor. Singapore: NUS Press. Pp. 44-79.

Sutter, Robert (2005), China's rise in Asia: Promises and perils. New York: Rowman \& Littlefield.

Taylor, Keith (1983), The birth of Vietnam. Berkeley: University of California Press.

Taylor, Keith (1998), "Surface orientations in Vietnam: Beyond histories of region and nation," Journal of Asian Studies 57, 4: 949-78.

Taylor, Keith (2013), A history of the Vietnamese. New York: Cambridge University Press.

The American heritage (1993), The American heritage college dictionary, $3^{\text {rd }}$ edition. New York: Houghton Mifflin Company.

Tilly, Charles (1989), Big structures, large processes, huge comparisons. New York: Russell Sage Foundation.

Tønnesson, Stein (2010), Vietnam 1946: How the war began. Berkeley: University of California Press.

Tran, Nhung Tuyet, and Anthony Reid (2005), "Introduction: The Construction of Vietnamese Historical Identities," in Nhung Tuyet Tran and Anthony Reid (eds), Viet Nam: Borderless histories. Madison: University of Wisconsin Press.

Truong Chinh (1968), "Doi doi nho on Cac Mac va di con duong Cac Mac da vach ra" [Forever being grateful to Karl Marx and following the path he pointed out]. Hoc Tap [Study], September 1968, 1-12 and October 1968, 10-27, 45-52.

$\mathrm{Vu}$, Tuong (2014), "The party v. the people: Anti-China nationalism in contemporary Vietnam," Journal of Vietnamese Studies 9, 4 (Fall 2014): 33-66.

$\mathrm{Vu}$, Tuong (2017), Vietnam's Communist revolution: The power and limits of ideology. New York: Cambridge University Press.

$\mathrm{Vu}$, Tuong, and Wasana Wonsurawat (ed.) (2010), Dynamics of the Cold War in Asia: Ideology, identity, and culture. New York: Palgrave Macmillan.

Turley, William (2009), The Second Indochina War, $2^{\text {nd }}$ edition. New York: Rowman \& Littefield.

Wallerstein, Immanuel (1974), The modern world-system I - Capitalist agriculture and the origins of the European world-economy in the sixteenth century. Berkeley: University of California Press.

Westad, Odd Arne (2005), The global Cold War: Third World interventions and the making of our times. New York: Cambridge University Press.

Westad, Odd Arne, and Sophie Quinn-Judge (eds) (2006), The Third Indochina War: Conflict between China, Vietnam, and Cambodia 1972-1979. New York: Routledge.

Whiting, Allen (1984), "Sino-Soviet relations: What's next?" The Annals of American Academy of Political and Social Science, v. 476 (Nov. 1984): 142-55. 
Whitmore, John K. (1985), Vietnam, Ho Quý Ly, and the Ming (1371-1421). New Haven, CT: Yale Center for International and Area Studies.

Whitmore, John K. (1986), "Elephants can actually swim," in David Marr and Anthony Milner, (eds), Southeast Asia in the 9th to 14th centuries. Singapore: Institute of Southeast Asian Studies, 1986.

Womack, Brantly (2006), China and Vietnam. New York: Cambridge University Press.

Woodside, Alexander (1971), Vietnam and the Chinese model: A comparative study of Vietnamese and Chinese government in the first half of the nineteenth century. Cambridge, MA: Harvard University Press.

Woodside, Alexander (2007), "The centre and the borderlands in Chinese political theory," in Diana Lary (ed.), The Chinese state at the borders. Vancouver: University of British Columbia

Press. 